\title{
An Analysis of Consumer Perceptions and Usage of Mobile Telecommunications Brand in the Maiduguri Township in Nigeria
}

\author{
Bintu Mustapha Chibok Ph.D ${ }^{1}$, Prof. S. K. Msheliza ${ }^{2}$ and Prof. W. C. Ndubuisi ${ }^{2}$ \\ ${ }^{\prime}$ Department of Marketing, University of Maiduguri, Borno State, Nigeria. \\ ${ }^{\prime}$ Department of Finance, University of Maiduguri, Borno State, Nigeria.
}

\begin{abstract}
This study examines the consumer perceptions and usage of mobile telecommunication in Maiduguri Township. The study considers consumer demographic variables and service providers' company brands which include MTN, Zain (Airtel), Globacom, Starcomms, Intercelluler and Mtel. Taking the entire consumers in Maiduguri as the population, it investigates the demographic variables of consumers between the age group of 18 and above currently using mobile telecommunication or who had once used mobile telecommunication services. A sample size of 500 was selected using purposive sampling technique. Specifically, the study targeted consumers at 20 different areas like car packs/stations, markets, and public institutions. Primary data were obtained through structured questionnaire and secondary data were obtained through company publications and standardised published materials from sources other than the company to develop the literature review. The data were then subjected to statistical analysis of Pearson's correlation, chi-square and descriptive statistics, using statistical package for social sciences (SPSS) version 13. The study reveals that Mobile telecommunication was significantly dominated by three companies with about $97 \%$ of market share where by only one company having more than 50\% of the market. Generally there was high and positive consumer awareness and perception towards all the mobile telecommunication providers. Consumers' demographic variables were important especially age and educational background of consumer on identification or knowledge about brand of mobile telecommunication.
\end{abstract}

Keywords: Consumers, perceptions, Telecommunication, Usage, Mobile brand

\section{Introduction}

When Nigeria gained her independence in 1960, there were very few functional telephone lines for the estimated 45 million populations. Even though there existed an organised national body responsible for provision and distribution of telephone services in Nigeria, it makes little or no impact on citizens who had access to such services. As the incumbent monopoly organisation NITEL, offered a limited and inefficient telephone network with only about 200,000 installed switching capacity and many applicants on the waiting list.

With the liberalisation of the telecommunication industry in 2001, mobile telephony has rapidly become the most popular method of voice communication in Nigeria. Growth has been so rapid that Nigeria was rightly described accurately as one of the fastest growing worldwide market for Mobile telecommunication. Through the Nigeria Communication Commission (NCC) the regulatory body, the Nigerian Government modernised and expanded the mobile telecommunications network and services by granting global system for mobile telecommunication (GSM) license to three service providers in January 2001. These providers included Mobile Telecommunication Network (MTN) Nigeria, Econet Wireless (now Airtel), and the first national carrier, NITEL (Mtel). In 2002, the second national carrier, Globacom, was additionally granted license to commence operation. Since then the Global system for mobile telecommunication (GSM) services and several other fixed wireless telecommunication services deliver telephone services to Nigerians and the world.

These telecommunication companies introduced great innovations and continued to provide aggressive and varied marketing strategies in order to establishing meaningful and differentiated presence through their names brands. They did this to increase company identification, attract and retain customers and improved market place efficiency and effectiveness. In view of the above, this research seeks to examine the consumer perceptions and usage in relation to consumer demographic variables and company brands of mobile telecommunication in Maiduguri Township. The service providers considered in this study include MTN, Zain(Airtel), Globacom, Starcomms, Intercelluler and Mtel.

\section{Literature Review}

Consumers are constantly involved in interaction of a multitude of sensory stimuli from ever increasing and sophisticated marketing communication. An understanding of perceptual processes is important to the 
marketer, since a consumer's decision to purchase a product will be influenced largely by the extent or way he/she interprets and forms positive meaning to the product information.

In the study of consumer behaviour, it is possible to conclude that perception is presented as one of personal factors determines consumer behaviour. A personal factor is the closest environment of a consumer, including everything that makes up the individual, his/her head and soul, which characterised his personality. Using sensory receptors and influenced by external factors, the person receives information, accepts and adapts it, forms his personal attitude, opinion, and motives that influence behaviour. Perception within this context is one of the principal personal factors, conditioning the nature of the consumer and his/her behaviour and other variables.

Analysing classifications proposed by marketing specialists, suggests that sensation, attention, interpretation and retention are the dominating elements of the perceptual process (Branyte et al, 2007). Crane and Klarke (1994) posit the theory of perceptual filters, based on the idea that the perceptual process is a set of filters, used for sorting and modifying a stimulus leading finally to stored memory of consumers. Indeed consumer cannot perceive all the stimuli in the phase of sensation; consumers do not react to every stimulus received in the attention phase lest they fail to understand the proper meaning of a stimulus while interpreting it. Essentially, they do not remember everything they have understood. The theory reflects the importance of evaluation and recognition of the elements of the perceptual process, seeking to activate and affect the consumer's perception. Every phase makes the consumer feel differently as the intensity of his/her reactions and the importance of external influence change.

According to Chernatony and McDonald, (1998), the challenge for marketers is to appreciate how all the marketing resources supporting a brand interact to produce the benefits that consumers perceive as being unique to a specific brand. Consumers interpret the meaning of the marketing activity behind a brand and project values onto the brand, endowing brands with a personality. They developed a useful framework to help understand the diverse types of brand-added value which includes; added values from experience; added values from reference group effect; added values from a belief that the brand is effective; and, added values from the appearance of the brand. Consumers form impressions of a brand from their packaging and develop brand preferences based on their attraction to the package design.

Demographic variable is an importance determinant of customer behaviours. Study shows that gender has significant moderating effect on perception, satisfaction- loyalty relationship. On this note, social identity theory proposes that attitudes are moderated by demographic, situational, environmental, and psychosocial factors (Haslam et al, 1993). According to the social psychological theories, consumers' evaluations are moderated, or in some cases mediated, by personal feelings of equity in the exchange, disconfirmation between desires and outcomes, individual preferences, social comparisons, and other complex phenomena. These theories strongly suggest that consumers' differences influence their attitudes.

Women are affected by sales process while men are satisfied with the impact of the product. That is, there is significant relationship and consistent differences in the levels of perception among demographic groups. Kotler and Keller (2006) and Karjoluoto et al (2005) report that demographic variables have an influence on the evaluation of different attributes related to mobile phone choice. Specifically, gender and social class will impact on the evaluations of the attributes as men belonging to higher social class seem to be more technology savvy. Decision making mainly follows a rational decision making process in which different attributes are evaluated, but also has some symbolic nature as brand was regarded as important among many study participants.

Product choice also is greatly affected by occupation, economic circumstances, spending income (level, stability and time pattern), savings and assets (including the percentage that is liquid) debt, borrowing power, and attitude towards spending and saving (Kotler and Keller 2006). Personality and self concept are important determinants of buying behaviour. Kotler (2001) defines personality as a set of distinguishing human psychological traits that lead to relatively consistent and enduring responses to environmental stimuli. Personality are characterised by such traits as self confidence, dominance autonomy difference, sociability, defensiveness and adaptability. Consumer's personality is very useful variable in analysing consumer brand choices. This is because brands also have personalities, and consumers are likely to choose brands whose personality matches their own. Brand personality is defined as the specific mix of human traits that may be attributed to a particular brand (Kotler and Keller, 2006). Aaker (1997) identifies the following as brand personality traits, sincerity, excitement, competence, sophistication and Ruggedness.

However, people from same subculture, social class and occupation may lead quite different lifestyle. Lifestyle is a person's pattern of living in the world as expressed in activities, interests and opinions. Marketers often search for relationships between their products and lifestyle groups (Kotler and Keller, 2006). Factors that relate to the user's surroundings and interactions with other people in his/her personal network of family, friends, colleagues and other important people also have important implications on consumers purchase. This is based on the fact that an individual's decisions and behaviours are not made solely by him/her, but rather are 
influenced by the opinions and recommendations of other important people. As a person is part of a social network, he/she normally interacts with others in daily life and talks and shares with others on what he/she sees, thinks and experiences (Pedersen, 2005). That is why, for example, word of mouth is known as one of the most effective channels through which positive and negative ideas and perceptions and spread in a social setting. Today, for every firm a critical question for its success is that how it can maintain its current customers and how it can make them loyal to the brands. Loyal customers play important role in building businesses by making different moves like buying more, by paying premium prices and most importantly providing companies different sets of new customers by positive word of mouth (Aydin and Ozer, 2004). In fact telecommunication companies lose their customer quite regularly. So it's very challenging task for the mobile phone operators to retain existing customers as well as bringing new customers towards their brands and creating loyalty in them. It happens in almost every industry but especially in telecommunication services, it is said that when customers are connected to a particular service provider or operator then their long term relationship with the operator is of great importance for the success of the company in the competitive market.

\section{Methodology}

The research considered consumers between the age group of 18 and above currently using mobile telecommunication or who had once used mobile telecommunication services before within Maiduguri Township. This group of consumers were assumed to have consciously and independently undergone through the decision process to acquire their mobile lines.

A sample size of 500 was selected using purposive sampling technique within the study area. They constituted users of all the six mobile telecommunication operators in Maiduguri. The researcher decided to use all the service providers available because of the need to objectively assess awareness and perception. Purposive sampling was used in order to enable the researcher include all categories of respondents with different characteristics and background which may unveil some implications on purchase of mobile telecommunications brands. Specifically, the researcher targeted consumers at 20 different areas like car packs/stations, markets, and public institutions.

Particularly, primary data were obtained through structured questionnaire. The secondary data were obtained through the concerned company publications and standardised published materials from sources other than the company to develop the literature review.

The data were then subjected to statistical analysis of Pearson's correlation, chi-square and frequencies and percentages, using statistical package for social sciences (SPSS) version 13.

\section{Results And Discusssions}

The issues relating to identification has to do with consumers' awareness and recall of brand name. It is important because awareness creates differences in consumer's perception and response to a brand.

Table1: Respondents' Ability to Identify Brands

\begin{tabular}{|l|l|l|}
\hline BRANDS & Frequency & Percentage \\
\hline MTN & 118 & $30.4 \%$ \\
\hline Celtel & 132 & $22.6 \%$ \\
\hline Globacom & 109 & $18.6 \%$ \\
\hline Starcomms & 34 & $5.8 \%$ \\
\hline Mtel & 4 & $0.7 \%$ \\
\hline Intercellular & 7 & $1.2 \%$ \\
\hline All of the above & 121 & $20.7 \%$ \\
\hline
\end{tabular}

Source: Field survey, 2010. $\mathrm{n}=461$.

The table1 shows the proportion of the respondents that were able to identify the different service providers. The index of respondents was used to arrive at the proportion. This was because some respondents were able to identify more than one service providers which resulted in respondents choosing more than one response, some identified all as very familiar to them. Consequently about $30.4 \%$ of the index of respondents identified MTN only, 22.6\% Zain(Celtel) only, $18.6 \%$ Globacom, 5.8\% Starcoms only, $07 \%$ Mtel only and $1.2 \%$ intercellular only respectively. The proportion of respondents that identified all the service providers is $20.7 \%$. This proportion claims that they can correctly identify all the service providers with their Logos and Slogans of advertisement.

The relationship between Brand identification and demography variable of respondents is shown on table using correlation analysis. 
Table 2: Results for the relationship between brand identification and demographic variables of respondents.

\begin{tabular}{lllll}
\hline Demographic variables & Sample & Correlation Coefficient & Significance value & Decision \\
\hline Age & 461 & $0.145^{* *}$ & 0.002 & Reject \\
Gender & 461 & 0.011 & 0.814 & Accept \\
Marital status & 461 & 0.040 & 0.393 & Accept \\
Occupation & 461 & 0.014 & 0.771 & Accept \\
Income & 461 & 0.161 & 0.021 & Accept \\
Education & 461 & $0.368^{* *}$ & 0.001 & Reject \\
\hline
\end{tabular}

Source: Computed from Field survey, 2010. $\mathrm{n}=461$

The results show in Table 2 explain that there is no relationship between, gender, marital status, occupation and income and ability of consumers' to identify a brand. The reason for this is that all the service providers are almost basically performing the same function which consumers perceive it as not significantly different from one another. Therefore, name or brand is not significant because there is nothing peculiar with all the service providers. In other words there is nothing done significantly different from those of competitors that will warrant consumer to see the service provider differently. This however conforms to Kotler's (2001) assertion that for a marketer to create a distinctive name the marketer has to enhance the value of product or service beyond its functional value and that differentiates the product or service from those of competitors.

The identification or awareness of different service providers does not depend on whether is a male or a female married or single, and level of income or whether employed or not. However this does not mean that, these variables, do not have relationship with awareness or perception of brands but it may be related through some other variables.

Table 3: Different Brands of mobile telecommunication used by respondents

\begin{tabular}{lllll}
\hline \multicolumn{3}{c}{ First choice } & \multicolumn{3}{l}{ Second choice } \\
\hline Brands & Frequency & Percentage (\%) & Frequency & Percentage (\%) \\
\hline MTN & 235 & 51.0 & 68 & 14.8 \\
Zain(Celtel) & 111 & 24.1 & 117 & 23.2 \\
Globacom & 90 & 19.5 & 46 & 10.0 \\
Starcomms & 13 & 2.8 & 19 & 4.1 \\
Mtel & 1 & 0.2 & 1 & 0.2 \\
Intercellular & 3 & 0.7 & 1 & 0.2 \\
Non response & 8 & 1.7 & 219 & 47.5 \\
\hline
\end{tabular}

Source: Field survey, 2010. $\mathrm{n}=461$

The Table 3 shows the distribution of respondents based on the brands of mobile telecommunication used. However the result is presented in two categories, each indicating respondents' brands used.

The researcher observes that most respondents use more than one service providers consequently using more than one line. This is not far fetched from the fact that the service providers are not adequately meeting customers' expectation. The reason could be that of infrastructural inadequacies leading to non availability of service, network coverage, connectivity problems and for the quest of easy accessibility and less charges. Therefore, customers use more than one line of mobile telecommunication to take advantage of getting their calls through at all times. The first part of the tables show about 235 respondents repressing 51\% use MTN, 24.1 use Zain(Celtel), 19.5 use Glo, and 3.7 use Starcoms, Mtel and Intercellular. However the second part of table shows that about $14.8 \%$ use MTN, 23.2\% use Zain(Celtel), 10.0\% use Glo and 4.5\% for Starcoms, Mtel and Intercellular. The non response of 219 representing $47.5 \%$ is implying that they use only one line as indicated in the first part of the table, while the other $42 \%$ of the respondents use more than one line of service provider. This analysis shows that the first three networks (MTN, Zain(Celtel) and Glo) are the most active network lines that people tend to use. These mobile telecommunication networks have wide coverage and tend to promote their network almost everyday and have consequently increased consumer recall rate and associations.

Table 4: Demographic variables, perception and usage of mobile telecommunication lines

\begin{tabular}{|l|l|l|l|l|l|}
\hline Variables & N & Chi-square value & Df & P value & Decision \\
\hline Age & 461 & 21.103 & 30 & 0.885 & NS \\
\hline Gender & 461 & 5.875 & 12 & 0.922 & NS \\
\hline Marital Status & 461 & 25.551 & 12 & 0.012 & S \\
\hline Occupation & 461 & 64.702 & 36 & 0.002 & S \\
\hline Income & 461 & 15.264 & 24 & 0.913 & NS \\
\hline Education & 461 & 69.557 & 36 & 0.001 & S \\
\hline
\end{tabular}

Source: Computed from Field survey, 2010. n=461

A Chi-Square test to show relationships between demographic variables and usage of mobile telecommunication indicate that age, gender and income seem to have no significant effect on how the brands are perceived and 
used. However, marital status, occupation and educational background of respondents have significant relationship ( $\mathrm{P}$ value $<0.05 \%$ ) with consumers' usage of mobile telecommunication as presented on Table 4 .

The wide range acceptance and usage of the mobile telephone services by consumers shows the level of perception of the consumers. There was a very high ability among respondents to correctly identify all the service providers with their Logos and Slogans of advertisement. The respondents not only use the mobile telephone services but also at the same time they use more than one service providers simultaneously.

Consumer's demographic variables generally have little or no relationship with basic awareness of brands names of mobile communication service providers. Gender, marital status, income and occupation have no direct relationship with the ability of consumers to correctly identify mobile telecommunications providers. However, there was significant relationship existing between age and education with the ability to identify mobile telecommunication brands. This finding shows that brand names of mobile telecommunication providers are significantly prominent among consumers. This is because consumers were able to identify each of the service providers by their names and logos. A consumer must become aware before evaluation of brand and brand equity; take place (Erden et al, 1999 and Nedundgadi, 1990).

Consumers' demographic variables have no relationship with perception and usage of mobile telecommunication with regards to age, gender and income. However, marital status, occupation and educational background of respondents have significant relationship ( $\mathrm{P}$ value $<0.05 \%$ ) with consumers' usage of mobile telecommunication. We should, however note that even though brand is expected to be an important determining factor that guide the perception and purchase of consumers, there are other factors, which include age, level of satisfaction, literacy, gender, awareness and reactions of friends and relatives that are equally important in consumers' purchase.

\section{Conclusions}

The study empirically explains the conceptual dimensions of consumer perspective that relates to perception and usage of mobile telecommunication. Consequently, meaningful insights can be derived and thus conclude that Mobile telecommunication was significantly dominated by three companies with about $97 \%$ of market share where by only one company having more than $50 \%$ of the market. Generally there was high and positive consumer awareness and perception towards all the mobile telecommunication providers. Consumers' demographic variables were important especially age and educational background of consumer on identification or knowledge about brand of mobile telecommunication. Older people who are highly educated are more conscious of choice of brands of mobile telecommunication.

Awareness is one basic ingredient of building brand equity and high positive perception creates differences in response to brands. Therefore, mobile telecommunication operators should concentrate on the marvellous and encouraging awareness of consumers to create higher brand recall and brand recognition in the consumers' memory and build brand equity.

Demographic variables are useful guide in consumer targeting and positioning and therefore, service providers should study the needs and consumer preferences in order to design a proper segmentation and targeting strategies.

\section{References}

[1] Branyte, T., Paunksniene, Z. and Rutelione, A. (2007). Peculiarities of Consumer Perception in the Aspect of Marketing to Women: Commerce of Engineering Decisions: ISSN 1392-2785, Engineering Economics 1(5) 50-58

[2] Crane, F. and Clarke, T. (1994). Consumer Behaviour in Canada: Theory and Practice: 2 nd ed. Dryden, Canada.

[3] Chernatony, L .and McDonald, M. (2001). Creating a Powerful Brand in Consumer, Service and Industrial Markets: ButterworthHeinemann London.

[4] Haslam, A., McGarty, C., Oakes, J. and Turner, C. (1993). Social Comparative Context and Illusory Correlation: Testing Between in Group Bias and Social Identity Models of Stereotype Formation: Australian Journal of Psychology, Vol. 45, 97-101.

[5] Kotler, P. and Keller, K. (2006). Marketing Management: Twelfth Edition Pearson Prentice Hall: India

[6] Karjoluoto, H., Karronen, J., Kesti, M., Koivumaki, T., Mannien, M., Palcola, I., Kistola, A and Salo, I. (2005). Factors Affecting Consumer Choice of Mobile Phones: Two studies from Finland: Journal of Euro Marketing 144 (3) 59-82

[7] Kotler, P. (2001). Marketing management: The Millennium edition, Prentice-Hall of India.

[8] Aaker, J. (1997). Dimensions of Brand Personality: Journal of Marketing Research 34 (3) 347-356.

[9] Pedersen, P. (2005). Adoption of Mobile Internet Services: An Exploratory Study of Mobile Commerce Early Adopters: Journal of Organisational Computing and Electronic Commerce, 15 (3) 203.

[10] Aydin, S. \& Ozer, G. (2004). The Analysis of Antecedents of Customer Loyalty in the Turkish Mobile Telecommunication Market European Journal of Marketing, 39, 7/8, 910-925.

[11] Erden, T., Swait, J., Broniarczyk, S., Chacravarti, D., Kapferer, J., Keane, M., Robert, J., Steenkamp, J.and Zettelmeyer, B. (1999). Brand Equity, Consumer Learning and Choice: Journal of Marketing Research 30 (4),7-12.

[12] Nedungadi, P. (1990). Recall and Consumer Consideration sets: Influencing Choice without Altering Brand Evaluations: Journal of Consumer Research, 17(December) 263-276. 